\title{
Preservation of Livonian Traditions
}

(2014)

\section{Ain Haas \\ Indiana University at Indianapolis \\ ahaas@iupui.edu}

The Livonian or Liv nationality has been on the edge of extinction for decades, as a distinct linguistic and cultural entity. This group within the Baltic-Finnic language family, inhabiting the central northern and northwestern parts of Latvia, ${ }^{1}$ has always been relatively small, compared to certain kindred groups like the Estonians and Finns. Their situation became critical during the last century.

Just how precarious it is became clear to this author at the time of first learning about them, through the presentation of Joel Ashmore Nevis at the FUSAC conference of 1988 at Windsor, Ontario. His talk on the attrition of case forms in Livonian due to Latvian influence presented the concept of "language death" to describe the process by which Livonian was becoming limited to speakers of advanced age and unlikely to survive much longer. The published form of his talk (1989) suggests that the term "language attrition" might be more appropriate, but still alludes to a perilous trend. Shortly thereafter, Harri Mürk, FUSAC's former president and my Estonian instructor when he worked on his doctorate at Indiana University, brought me the folk song record album Liivi (Tallinn: Melodia, 1989), an anthology compiled by Ingrid Rüütel and Kristi Salve. He also recounted an incident he observed when the performers at the 1989 Baltica Folklore Festival in Tallinn walked past a crowd of observers. Someone in the crowd yelled out, "Elagu liivi rahvas!" [Long Live the Liv People!]. One of the Liv performers gave this breathtaking response: "Liiga hilja!" [Too Late!]. Ominous headlines have appeared in the news recently, such as: "Riga Journal; Baltic's Onetime Rulers Have Shrunk to a Handful" (Michael Specter, New York Times, Dec. 4, 1997), "Julgi Stalte-eelviimane mohikaanlane?" [JS--The Next-to-Last Mohican?] (Marko Mägi, Eesti

\footnotetext{
1 The aboriginal territory of the Livs was much smaller than the province of Livonia in the Russian Empire, and partially outside it. The tsarist administrative unit of Livonia included the Liv enclave of the western part of the North Central Latvian district of Vidzeme, but also the eastern part of that district, beyond the Liv settlements; the Eastern district of Latgale; the South Estonian mainland and Saaremaa Island. The Courland enclave of Livs was in the tsarist province of Curonia, not in the province of Livonia.
} 
Ekspress, July 26, 2001), "Suri viimane vanema põlve emakeelne liivlane" [The Last Mother-Tongue Speaker of Livonian of the Older Generation Died] (Jaak Prozes \& Ott Heinapuu, Eesti Päevaleht, March 9, 2009), and "Maailma viimane emakeelne liivlane sai 100-aastaseks" [World's Last Mother-Tongue-Speaking Liv Reached the Age of 100] (Tapio Mäkeläinen, Fenno-Ugria, March 19, 2010). Even in a scholarly journal, an article with the alarming title of "Livonian--the most endangered language in Europe?" appeared (Moseley, 2014).

The following report provides an overview of the process of decline and recent stabilization at a precarious point. The roles of native intellectuals, supporters among other nationalities, political factors, and technology are clarified. The prospects for maintaining or improving the Livs' situation are also discussed.

The author does not claim special expertise in Livonian studies, but has amassed a respectable collection of relevant publications and recordings, and can offer summaries of Estonian-language materials. I have also had some contacts with Livs and Livophiles, including a meeting with Helmi Stalte at the Fourth International Baltic Psaltery Symposium in Riga in 2000, hosting her daughter Julgi Stalte in Indianapolis during a visit in the same year (including a joint performance with the local Estonian-Latvian folk music ensemble, Hedgehogs), attending the inaugural meeting of the Livonian Friends' Union in Tartu in 1998, and corresponding with Liv and Estonian linguists. Liv tunes have been part of my folk music repertoire for 30 years, and there have been frequent discussions of Livrelated topics with Estonian and Latvian musicians, based on the available information about these tunes, as well as their cultural and comparative context.

\section{Rapid Decline}

The Liv population count is uncertain in the early historical record, during the arrival of German Christian conquerors and missionaries in the 12th century, but a figure of 20,000 has been offered (Vääri, 1970: 77). Their territory was only a small part of Latvia, and there was already considerable ethnic mixing and assimilation in progress. The Livs' Curonian enclave seemingly absorbed influences and inhabitants from a pre-Viking Scandinavian outpost on the Latvian coast, and Scandinavian influences have been identified in Liv jewelry, names for persons and places, etc. After involvement in the Viking trade network, some Livs relocated to the Daugava (Väina) River (including Riga) in the early 10th century, and others moved to the Gauja (Koiva) River in the 11th century. Archeological finds suggest that this resulted in considerable mingling with Scandinavians, Baltic tribes (Semigallians and Lettgallians), and even Saaremaa Island Estonians. In nearby Idumea (same root 
as Vidzeme), chroniclers of the early 13th century noted that Livs had blended with Lettgallians in ethnically mixed settlements. Likewise, in border areas, Livs often lived in mixed settlements with the abovementioned groups, as well with Curonians (Zemītis, 2011: 78, 80-85).

The population declined as a result of casualties of war--during fighting against the German Crusaders, between the early Liv converts and their pagan kindred, and in campaigns on behalf of their conquerors against pagan neighboring peoples. Plagues also took their toll, such as the one that struck Liv villages in 1206 and contributed to the capitulation of the Vidzeme enclave much earlier than the Kurzeme enclave's fall in 1267 (Vääri, 1998: 6-7). The geographical isolation of the latter group, with vast forests and bogs between them and the invaders' center of power in Riga, protected them to some degree from such onslaughts. The Liv population might have rebounded from such threats to their physical survival, as did neighboring peoples, but another peril arose under the feudal order imposed by the conquerors. Many Livs and Latvians were relocated between estates and ended up living in ethnically mixed settings, which forced the less numerous Livs to become bilingual and accelerated assimilation into the larger Latvian group (Vääri, 1970: 78).

The pace of decline in the number of people identified as Liv is difficult to document for several centuries, due to the lack of systematic recordkeeping. There are only sporadic mentions of Livs in historical documents before the 19th century. The publication of a Lutheran text in 1525 with Estonian, Latvian, and Livonian sections indicates that there were enough Livs at that time to make a trilingual book for religious instruction seem worthwhile, but a century later in 1622, the chronicler Thomas Hiärne reported extensive assimilation into the Latvian majority (Vääri, 1998: 7-8). ${ }^{2}$ The first systematic counts were done by Andreas Johann Sjögren from Finland, who reported finding only 22 Livonian speakers in 1846 in northern Vidzeme, in a single village in the Salaca (Salatsi) River area near the Estonian border, but a much larger figure of 2,324 in 1852 among several Curonian Peninsula villages (Vääri, 1970: 78; Ernštreits, 2013: 13-14). Similar figures were obtained in the 1864 census: 24 Livs in Vidzeme and 2,313 in Kurzeme (Cimermanis, 2003: 12).

The stark contrast in Sjögren's two counts shows how the pace of assimilation in the two Liv enclaves was rather different. In the western part of the Vidzeme region (north of Riga), Livs were already assimilated into the Latvian majority of the population in the mid-19th century. The last known speaker there died in 1868, according to Vääri (1970: 80), but Cimermanis (2003: 23) cites reports that the language endured among some individuals into the early 20th century. Some Livs

2 Vääri (1998: 8) cites Thomas Hiärn(e), Ehst-, Lyf-und Lettlaendische Geschichte (1622). One edition was published in Mitau [Jelgava, Latvia] by Johann Magnus Werht in 1794. 
also lived across the border in southwest Estonia in the Häädemeeste district south of the city of Pärnu, and became assimilated into the Estonian population there around the same time (Karro, 1998). In the northernmost part of the Western Latvian district of Kurzeme (Courland), the assimilation process was somewhat slower, and a dozen Liv fishing villages at the tip of the peninsula endured into the 20th century. Livs were more involved in fishing, sea transport, and trade than their Latvian neighbors, and both occupational and geographical segregation helped maintain the Livonian language in this enclave (Cimermanis, 2003: 25-26).

Shortly after the onset of World War I, the Livs' coastal enclave was seized from Russian control by German forces, which led to an evacuation of the Liv inhabitants to the interior of Latvia, to Estonia, and to Russia. Many did not return after an absence of four years or more, as their homes and fishing equipment had been lost or destroyed during the wartime occupation. The 1920 census yielded a figure of 831 Livs in newly independent Latvia, but that same year the Finnish linguist Lauri Kettunen offered an estimate of 1,500 Livonian speakers, almost twice as high. The latter figure seems more plausible, as an official count in 1925 yielded a figure of 1,238, of which nearly all (97.5\%) were living in their traditional enclave in Courland (Blumberga, 2011a: 136-137).

\section{Interwar Renaissance}

The sudden post-war increase in officially recorded Livs seems attributable partly to the return of the wartime evacuees from neighboring countries, and partly to the rise in self-esteem that followed the increased attention of Finnish and Estonian researchers to Liv traditions (Blumberga, 2011a: 137). Livs became aware of the keen interest in their language and lore on the part of such distinguished visitors as the Finnish linguist Lauri Kettunen, employed initially at Tartu University in Estonia and later at Helsinki University in Finland, and his student, the Estonian folklorist Oskar Loorits. They made their first expedition to Liv territory in 1920, on behalf of the Tartu University Mother-Tongue [Estonian Language] Society (Tartu Ülikooli Emakeele Selts). The Estonian ethnographer Ferdinand Linnus (previously Leinbock) came to study their fishing traditions in the 1930s and filmed their activities. Also in the 1930s, the Finnish pastor Helle Kalervo Erviö travelled periodically from his base in the northeast Estonian town of Narva, where he served an Ingrian congregation, to the Livs' territory, to minister to them in their own language. The Riga-based Livonian Friends' Society of Latvia gathered information for Liv calendars and a dictionary, which were compiled by the philologist Laimons Rudzītis (Vääri, 1970: 81,83; Blumberga, 2011a: 142). 
Liv intellectuals also played a crucial role in raising self-awareness and selfesteem. One of the most prominent of these was Kōrli (Karl) Stalte (1870-1947), who published the first volume of Livonian-language poetry in 1924 in Tallinn, titled Lìvo lōlõd [Livonian Songs]. With funding from Finnish supporters, he also issued songbooks (1929 and 1933). He wrote the lyrics to the song Min izāmō, min sindimō [My Fatherland, My Land of Birth], which became the Liv anthem. (The same melody, composed by the German-Finnish Fredrik Pacius in 1848, is also the Finnish and the Estonian anthem, which are similarly titled.) Stalte became the second editor of the Liv cultural magazine Lìvli, founded by Aṇdrõks Štāler in Jelgava in 1931, when this monthly's headquarters moved to the Liv village of Irē in 1933. With assistance from Professor Kettunen, Stalte translated the New Testament into Livonian, and had it published in Helsinki in 1942.

Another key figure was Pētõr Damberg, who trained at the Jelgava Teachers' Institute. One of five native instructors of the Livonian language for an annual average of 100 pupils taking optional Livonian classes in schools (Ernštreits, 2012), he prepared a Livonian textbook for schoolchildren, Jemakiel lugdõbrāntõz skūol un kuod pierast [Mother Tongue Reader for School and Home], published in 1935 in Finland. With financing he obtained from abroad, he arranged choir concert tours and study trips that took Livs to Estonia and Finland, giving them exposure to other Finnic societies that could serve as models for Livs' aspirations in terms of a national awakening. He wrote poems, translated works from other languages into Livonian, and assisted other researchers in the collection of materials on the Liv language, folk poetry, and folk music. He served $\mathrm{o}^{3} \mathrm{n}$ the editorial board of Stalte's magazine, and was invited by the Estonian newspaper Postimees to write regular articles on Liv affairs (Hint, 2009).

The efforts of such Liv leaders were not limited to individual projects, but were also channeled into organized forms, which drew other members of their community into activism in the interwar era. Livõd It [Liv Union] was formed in 1923 in Irē, also known as Piški-Īra or Mazirbe. It was led initially by Kōrli Stalte, but longest by his successor, the circuit-riding Livonian language teacher Mart Lepste. $^{3}$ Its mission statement emphasized the importance of maintaining the Livonian language, making information and instruction available, and improving the economic and social status of Livs. Only about one tenth of Livs became members,

3 Lessons in Livonian were optional in the elementary schools of the Liv villages, and limited to one or two hours per week. Lepste made his rounds by horse, moving from one village to another, and slept in the schoolhouses. Due to the lack of Livonian instruction in high schools, the Tartu Teachers' Seminary provided opportunities for Liv students of both sexes to study in Estonia (Vääri, 1970: 81, 83). 
but its impact as the only national organization of the Livs was tremendous (Blumberga, 2011a: 142).

One of the first accomplishments of this organization was arranging a Liv song festival for Midsummer in 1924, with the participation of several village choirs. These had been founded during the preceding two years, the earliest one being directed by Margarete Stalte, daughter of Kōrli Stalte (Blumberga, 2011a: 142-143; 2011b: 349). Such organized singing under a choir director was a new form of activity that Estonians and Latvians had adopted from the Germans.

In the 1930s, the Liv Union's efforts focused on obtaining funding for a Liv People's House (or Community Center), which could serve as its headquarters and provide space for a variety of cultural activities. Due to the limited resources of the Liv community, outside funding was crucial. The largest contribution (about two fifths) came from Finland, and roughly equal amounts (about one fifth each) came from the rest of Latvia, Estonia, and the Livs themselves. Hungary also made a small donation. Construction of the modern building in Irē began in October 1938 and was completed in less than a year (Blumberg, 2011a: 143). Unfortunately, the outbreak of World War II and subsequent Soviet occupation interfered with the Livs' ability to use the facility as intended for many years, but eventually (a half century later), it did become the envisioned focal point for Liv activities.

The Liv Union lobbied unsuccessfully for a Liv administrative district within the Latvian state. This would have promoted the use of Livonian as an official language and thereby raised its prestige. Ernštreits (2012) argues that the main reason for the Livs' bilingualism is that no major institution used their language. Thus it could not be used as a means of communication beyond their own families, acquaintances, and small ethnic community.

Despite this setback, the interwar period was a time of national awakening among Livs, when the decline in numbers slowed down and may have even been reversed temporarily. Eduard Vääri, professor of Baltic-Finnic languages at Tartu University, reports an impressive rise in the number of Livonian speakers between World Wars I and II--more than doubling ${ }^{4}$ to 2,000. The latter figure is higher than other counts of this era, but Vääri may have taken into account individuals of mixed heritage, the reluctance of some Livs to declare themselves as such, or the growing number of Livs living outsi ${ }^{4}$ de their traditional territory. A 1928 count by the Liv

\footnotetext{
4 There seems to be an inconsistency in Vääri's reports of the number of Livonian speakers at the end of World War I. His 1970 article puts the number at 500-600 at the start of the interwar period (late 1918, before the return of wartime evacuees?), but his 1998 article sets it at 800-900 in 1920, which fits with the census result of 831 that year. Both articles indicate the figure was 2,000 on the eve of World War II, more specifically in 1939 in his later article. The discrepancy could be explained if the earlier work focused on the Courland enclave and the latter work included other
} 
Union yielded a total of 1,726 Livs--1,425 (83\%) in the Courland enclave, plus 301 $(17 \%)$ residing elsewhere in Latvia. The census of 1935 yielded a much lower figure of 944 self-identified Livs, of which 877 (93\%) lived in the Courland enclave and 67 (7\%) elsewhere. ${ }^{5}$ Among the 892 whose census cards could be located later for the analysis the demographer I. Mežs did in 2000, 792 (82\%) could speak Livonian, but only a quarter used the language in their own homes. The inability to speak Livonian was especially evident among those born after 1905 (i.e., under age 30 at the time of the 1935 census), where it was four times more common than among the older self-identified Livs. Also in 1935, a study by Edgar Vālgamā $\overline{ }^{6}$ showed a count of 1,205 Livs, evidently identified on the basis of their parentage, living in their Courland villages, with an unknown number elsewhere. Some 820 of these $(68 \%)$ were able to speak the language. The growing number of Livs who could not communicate adequately in their traditional language is reflected in the Liv Union's decision to switch to Latvian for conducting most of its business in the late 1930s (Blumberga, 2011a: 136-139).

One factor impeding expressions of Liv national pride was the growing nationalism and authoritarianism of the Latvian regime, reflecting a more general trend in European countries of the time. It is not surprising that the government would be suspicious of foreigners from Estonia and Finland who encouraged separatist tendencies among their linguistic kindred in Latvia. The Livs' singing of their own anthem, so similar to the Estonian and Finnish ones, and their display of a new national flag ${ }^{7}$ did not help matters. In the 1920s, Oskar Loorits encountered criticism in Latvian newspapers of his expeditions among the Livs, and he was declared persona non grata and ordered to leave Latvia after a 1937 conference

parts of Latvia in its count, but that is not confirmed in the articles. The difference could also be due to more sources of information being used for the later article, but again that is not stated.

5 According to Blumberga (2011a: 138), the decline in the recorded number of Livs living outside their Courland villages (in 1928 vs. 1935) suggests that those who relocated tended to change their self-identification from Liv to Latvian.

6 Vālgamā (Vaalgamaa in Estonian transcription) was a Liv theology student in Helsinki, who finished his training there in 1939. His plan to become the Livs' pastor was disrupted by the Soviet invasion of 1940 (Vääri, 1998: 18).

7 The Liv flag, first used by the Liv Union in 1923, has the same basic design as the Latvian one, but with different colors. There are three bands of color, with the middle one half as narrow as the upper and lower ones. The bands of green (top), white (middle), and blue (bottom) symbolize the shoreline landscape of forest, sand, and sea. The Latvian flag, officially adopted one year earlier, also has a narrow white band in the middle, but the rest is a deep red color, symbolizing the blood of self-sacrifice of a fallen hero or the readiness of the Latvian people to shed their blood to defend their freedom. 
(Blumberga, 2004). ${ }^{8}$ Latvian officials were not consistently working against the Liv awakening, however. When Pētõr Damberg asked in 1935 for permission to distribute his Livonian textbook in schools, the application was rejected initially, but after lobbying by Finnish supporters, who appealed to the Latvian embassy in Helsinki, and the addition of some Latvian patriotic material to the text, Damberg got his wish (Hint, 2009). Pastor Erviö was denied a work permit in 1936, which interrupted his commute from Estonia to serve his Liv congregation. When questioned by the Finnish ambassador in Riga about this decision, the Latvian Foreign Ministry justified it by pointing to Estonian newspaper articles that had been critical of Latvian policy toward Livs, Estonia's adoption of a law banning foreign clergy from serving in Estonia (which also resulted in Erviö's ban from serving his Ingrian congregation in Narva), and the "insulting and harmful propaganda" being disseminated in Estonia and Finland regarding the treatment of Livs. After the Finnish ambassador protested the host country's "fanatical nationalism" in this matter, Latvia's ban was lifted the following year, so Erviö could resume his ministry among Livs for a few more years. ${ }^{9}$

8 Via the Estonian Embassy in Riga, Loorits was told that the ban was a result of his speeches and newspaper articles about Livs. Later he learned via the Estonian Foreign Ministry that he was wrongly blamed for an article (signed with the same initials OL--by Otto Liiv [historian and archivist]) that argued for the Courland Liv district to be reassigned to Estonia, which would enable Estonia to control both sides of the narrow entrance to the Bay of Riga. Loorits was offered the opportunity to return to Latvia, if he promised to write only pro-Latvian articles afterward. He said he had no political agenda in his writings, but could not violate his conscience by promising to adhere to such a guideline (Blumberga, 2004). Latvia had just lost its claim to the disputed island territory of Ruhnu (Runö) in the middle of the Bay of Riga, when the Swedes living there expressed their preference in a 1922 referendum to be under Estonian rather than Latvian control; this enabled them to join thousands of other Swedish speakers living in Estonia's coastal area. There may have been Latvian concern that Livs would seek a similar solution to their isolation from their linguistic kindred. The Courland Livs had a long history of intimate contact with Estonia's Saaremaa Islanders, as reflected in loan-words on both sides of the narrow strait separating them (Pajusalu, 2000).

9 During Pastor Erviö's last visit to Liv territory in 1939, he became discouraged about the dwindling number of young speakers of Livonian. In all but two of the villages he visited, almost all the children receiving Christmas presents were unable to speak Livonian. He reached the conclusion that further such visits were pointless (Blumberga, 2011c: 182-184). 


\section{Soviet Era Setback}

In World War II, Livonians had to evacuate their Courland enclave again, with many failing to return. Under the Soviet occupation, some were deported to Siberia and others faced severe restrictions on their movements and activities, as well as outright hostility from the new regime. Soviet officials were concerned about the possibility of defections to the West and the arrival of spies and saboteurs in the border zone. Soviet border guard stations and military units were inserted into Liv territory. The ruling Communist Party's ideology favored "proletarian internationalism" and denigrated what Karl Marx called "the idiocy of rural life." This meant the discouragement of parochial or nationalist tendencies among minorities, encouragement of ethnic mixing, assimilation into a Russian-speaking cultural environment, abandonment of traditions, adaptation to modern technology, centralization of decision-making, collectivization of enterprises, etc. All of these processes made it harder to maintain the Livonian language and culture.

About a third of the Liv population had fled abroad during the war, and many others had relocated to other places in Latvia, as a result of the new Soviet regime's restrictions on access to the coast. Only some 800 Livonian speakers remained in Latvia after World War II (Vääri, 1998: 20-21). ${ }^{10}$ The residents of the fishing villages were not allowed to engage in their traditional livelihood there, and were compelled to join fishing cooperatives operating out of the larger harbors or to seek employment in Latvia's towns. Farming was not a viable alternative along the coast, where there was generally sandy soil of low fertility. Lumbering was a source of supplementary income, as can be seen in the ethnographic film Linnus made (1940), but large-scale logging was unsuitable in a landscape where patches of forest were interspersed with sand dunes, low wetlands, and bogs, as can be seen from the photos in Sāmite (2015). The population of the villages was increasingly dominated by the elderly, and the younger generations found themselves working in large collective enterprises, with many Latvian and/or Russian co-workers and very limited opportunities to converse in Livonian. Many Livs sold their buildings to outsiders seeking summer lodgings, or simply abandoned their homesteads, and then scattered to search for jobs elsewhere. Assimilation was also accelerated by Soviet officials' discouragement of Livonian language use and folkloric activities in general (Vääri,

10 There is also a discrepancy with regard to the postwar figure. Vääri's earlier work reports that a 1948 expedition led by the Estonian linguist Paul Ariste found only 500-600 Livonian speakers in Courland, with few youths among them (Vääri, 1970: 83-84). His later work likewise describes Ariste's expedition, followed by a count of 800 (1998: 20-21). The discrepancy could be explained if Courland vs. all of Latvia is covered in the counting, but that is not made explicit. 
1998:21; Blumberga, 2011c: 144; Šmidchens, 2014: 279-280). Livonian lessons were excluded from the curriculum in village schools.

Censuses revealed a drastic population decline, especially at the beginning of the Soviet period. In 1959, there were only 185 officially registered Livs within the Latvian Soviet Socialist Republic. Twenty years later, the figure dropped to 107. In 1989, just before the restoration of Latvian independence, it rose again to 135 (Blumberga, 2011c: 144). This reflects a belated recovery of ethnic pride, under a somewhat more lenient regime in the late Soviet era.

\section{The Singing Revolution}

In the late 1980s, when the Gorbachev regime allowed more independent organizational activity, nationalist movements reemerged in all three Baltic countries. This set in motion the dissolution of the Soviet Union and the recovery of national independence for its republics, after Soviet hardliners failed in their coup against Gorbachev in August 1991 and the Russian president Boris Yeltsin eclipsed him. This process involved non-violent tactics such as the Baltic Chain demonstration, song festivals (where forbidden pre-Soviet anthems were sung and national flags were unfurled), and declarations of autonomy and eventually outright independence by legislators, which reporters could cover and interpret without the censorship that characterized most of the Soviet period, due to Gorbachev's policy of glasnost or openness. The most impressive and photogenic demonstrations may have been at the song festival grounds in Tallinn, culminating in the Eestimaa Laul [Estonian Song] event of September 11, 1988, when some 300,000 people gathered to sing Estonian patriotic songs and hear pro-independence speakers. There were some casualties of Soviet repression in Latvia and Lithuania, but basically the process of recovering national independence was non-violent and came to be characterized as "The Singing Revolution," especially in Estonia.

The suitability of this phrase to describe the events in the other Baltic countries may seem questionable, since there were no large Latvian or Lithuanian song festivals that could rival Estonia's, but Estonian activists gave credit to their counterparts in the other countries for taking the first bold steps to regain independence. In Latvia, singing at smaller events did play an important role in rekindling open expressions of nationalist sentiment, and Livs can be credited as instigators of the process that led to the recovery of national independence for Latvia. Thus, there was a sort of "Singing Revolution" in Latvia, which preceded the more famous one in Estonia, and Livs played a role that was much greater than one would expect from their very small population size. 
The central figures in this drama were Dainis Stalts (1939-2014) and his wife Helmi Stalte (1949-), both Liv folklorists. ${ }^{11}$ They were members of the Riga-based choir Livlist [Livs], one of two Liv musical groups started in 1972. The other was Kāndla (named after the Baltic psaltery, known to Estonians as kannel or in olden times kandel), featuring folk instruments, in the coastal town of Ventspils (Blumberga, 2011a: 144). The folklorist couple was less interested in artsy choral arrangements than in ethnographically authentic traditional singing, so they started their own group with the Latvian name Skandinieki [Vowel Sounds] in 1976. Inspired by a similar Estonian group called Hellero in Tartu, this first urban-based folklore ensemble of Latvia includes Latvian members, uses folk instruments, and sings both Liv and Latvian tunes, connected to traditional seasonal rituals or lifecycle celebrations (Šmidchens, 2014: 275-278). Some members dress in archaicstyle Liv costumes, with elements dating back to before the German conquest of the 13th century. The Liv repertoire comes from family heritage, archival recordings which Pētõr Damberg and others made, and the book Volkslieder der Liven (1936), a treasure trove of folk songs assembled by Oskar Loorits, with transcriptions and lyrics translated into both German and Latvian.

Soviet officials were nervous about "unsanctioned attempts to revive folklore traditions." A 1972 memo from the secret police (KGB) to the local Communist Party noted that folklorists' efforts to preserve Latvia's cultural heritage and uniqueness challenged Soviet power and aligned with the goals of émigré organizations. Dainis Stalts and Helmi Stalte were troublesome not only for these reasons, but they felt impelled to become politically active, when the Livs were removed from the official list of Soviet nationalities in 1977 and could no longer opt for such an identity in their passports. The couple circulated a petition in 1978 to protest the decision, signed by some other Livs and Latvian cultural figures. Although the decision was rescinded eventually, the couple suffered several years of repression as a result. In 1981, their difficulties in finding stable employment ended when they were hired as researchers at the Ethnographic Open-Air Museum in Riga--a major tourist attraction, central meeting place for folklore enthusiasts from various regions, and base for expeditions into the countryside--and the museum director defied orders to fire them. Yet they still faced interrogations, home searches and surveillance by the secret police; confiscation of their old books; anonymous threats via telephone calls and other forms of harassment; and more conventional researchers' harsh critiques of their authenticity, knowledge, and professionalism.

11 Dainis Stalts came from a Latvianized Liv family from the Vidzeme enclave. His mother was of Salaca (Salatsi) River Liv origin, and his father was of Gauja (Koiva) River Liv origin. Helmi Stalte's roots were in the Courland Liv enclave. Both were born in Riga, according to their biographic entries in the virtual encyclopedia Latvijas jaudis. 
When Gorbachev became the Soviet leader, the harassment and criticism subsided (Šmidchens, 2014: 275-282).

Despite such efforts to intimidate them, the Liv folklorist couple only became more outspoken and more brazen in their defiance. They found old verses that could obviously be interpreted as criticism of the current regime, got audiences to participate in singing and rituals and thus made traditions seem more viable and relevant to them, and raised both Livs' and Latvians' self-esteem and ethnic pride. When the Baltica Festival was held in Riga in 1988, they participated with likeminded ensembles from neighboring countries in smuggling the forbidden national flags to the stage, unfurling them before the public, and parading with them in the streets afterward. The local media initially avoided showing images of the flags, but such censorship did not last long (Šmidchens, 2014: 276-278, 283-285). The high regard in which such leadership of the resistance movement was held after Latvia regained its independence can be seen in the election of Dainis Stalts to the Saiema or Latvian parliament, where two other Livs have also served (his son Dāvis Stalts and Ilmars Geige).

Julgi Stalte (1978-), the daughter of Dainis and Helmi, participated in the concerts and recordings of Skandinieki and the Stalti Family, but has also had a successful career as a featured performer with other ensembles. She studied folk music at the Viljandi Academy in Estonia, plays violin and kāndla, and sings old tunes in Livonian to the accompaniment of folk and modern instruments played by family members and other Livs, musicians in the Liv-Estonian group Tu'lıli Lum [Hot Snow] or musicians in the Liv-Latvian group Kalā Jeng [Spirit of the Fish]. A recent Estonian television documentary, Julgi vägi [The Power of Julgi] by the Estonian director Liivo Niglas (2005), shows her performing at folk festivals with Tu'llli Lum, serving as tour guide for an Estonian group's tour of -Liv territory in Courland (including a viewing of the large fishing boats that were ordered destroyed in the 1950s), preparing for a performance at the Liv People's House in Irē (Mazirbe), and leading groups of young singers and dancers of Liv heritage.

\section{Scholars' Contributions}

Another important Liv activist who felt impelled to fight against the indifference and discouragement of the Soviet period is Valts Ernštreits (Valt Ernštreit in Livonian, 1974-). He recalls the contradiction between his history teacher's statement that the Livonians had become extinct in the 13th century (misinformation which Julgi Stalte also heard in her history class) and his discovery of his father's aunt's list of Livonian expressions with Latvian equivalents. His interest in the Livonian language began 
during the reemergence of overt nationalism in 1987-88, at the onset of his teens, and led him to study at Tartu University, where he wrote a doctoral dissertation on written Livonian (2013). He worked with an Estonian professor specializing in Livonian, Tiit-Rein Viitso, to produce the Livonian-Estonian-Latvian dictionary (Viitso \& Ernštreits, 2012). ${ }^{12} \mathrm{He}$ has taught Livonian and other Finno-Ugric languages at Tartu University, the University of Latvia, and at the Liv Summer University, and is currently working with Viitso on a Livonian grammar book. He has compiled two anthologies of Livonian-language poetry, including some of his own works in the first volume (1998) and translations of Liv-themed poems from other languages in the second volume (2011). He was involved in setting up the Web site www.livones.net of Līvõ Kultūr Sidām [Liv Culture Center], which offers information in three languages (Livonian, Latvian, and English) on Liv history, folklore, culture, literature, art, music, and organizations.

Renāte Blumberga (1971-) is a Liv historian, who got her doctorate at Helsinki University and is affiliated with the Liv Culture Center in Riga. She has written many articles on the Livs' recent history, including four of the chapters of a recent anthology with a title that translates as Livs: History, Language, Culture (Blumberga, Mäkelainen \& Pajusalu, 2011). This book involved not only Finnish and Estonian co-editors, but several other Liv researchers and artists.

Such scholars represent a new development. They are Livs who earned high degrees by doing research on their own ethnic heritage. They also pursued successful careers that combined specialization in Liv topics with service to their ethnic group. Their mentors were professors in Estonia and Finland, where Liv students could be inspired by immersion in a Finnic-language environment, extensive library and archival collections of Liv or related materials, opportunities to study the Livonian language in long-established instructional programs, and others' expressions of interest in their heritage.

Such encouraging conditions are also emerging in Latvia. There is not the same kind of immersion experience in everyday life, but the University of Latvia has offered Livonian courses regularly in recent years. An introductory Livonian textbook for Latvian speakers was prepared by the university's Estonian linguist

12 The printed version is in only one direction, with Livonian entries and their Estonian and Latvian translations. In the online version, one can begin with a word in any of the three languages to seek equivalents in translation.

The dictionary has valuable information not just about the Livonian language but also the culture, as this author discovered when searching for the Liv word for bagpipe. It is ilgoma' $g$ 'seal stomach' (hülge magu in Estonian). This term reveals that Livs were familiar with a version of this instrument which was made of the same material that Estonians preferred, rather than the animal skins that Latvians preferred. Livs seem to have come up with their own word for the instrument, rather than adopting the Estonian torupill or Latvian düdas. 
Kersti Boiko (2000), and published by the Liv Union, which was resurrected in 1988. Compared to those who go to Tartu or Helsinki, students of Liv heritage who stay in Riga have more opportunities to converse in Livonian with their own kind, not only at the university but also in various activities organized by the cultural organizations that reemerged in the late Soviet and post-Soviet periods.

There is a market for scholars' and other experts' Liv-themed works, which is much larger than the small community of Livs or Finno-Ugric specialists wanting to explore their heritage. In Estonia, there is a real appetite for books about Livs, as indicated by the fact that the anthology of Blumberga et al. (2011) sold out within a year and has not appeared in used book stores yet. Earlier publications by Estonian authors that have appealed to the general public include a book on Liv proverbs, compiled by Vaina Mälk (1981) with Pētõr Damberg's help and featuring a listing of equivalent expressions in the Estonian, Votic, and Latvian languages; ${ }^{13}$ a book of folk tales by Kristi Salve (1995), based on her expeditions and suitable for young readers; and the tomes of Oskar Loorits on Liv folk beliefs, part reprinted and part newly issued (1998 [1926-1928] \& 2000).

Linguists are discovering links between Livonian and the Estonian dialects of Saaremaa Island and Häädemeeste-Saarde (SW coast) districts, so people with roots in those areas might be especially interested in learning of Liv influences or vestiges. ${ }^{14}$ Karl Pajusalu, who learned the Häädemeeste dialect in his childhood, is among those who have explored lexicological links (Pajusalu et al., 2009; Pajusalu, 2010). Urmas Sutrop presents documentary evidence not of mere influence across the Latvian-Estonian border but of Livs' formerly being the primary occupants of the Estonian coast south of Pärnu, which would thus make Livonian an extinct aboriginal minority language of Estonia (2011: 115). If such an understanding spreads among Estonians, interest in Liv-themed works would surely grow.

In Latvia, the potential market for Latvian-language books on Livs is quite large, considering that many Latvians are aware of Livs in their family tree, especially in the Vidzeme and Kurzeme regions, as well as in Riga. Valda Šuvcāne (1923-2007) recently published books on Liv village life (2002) and folklore (2003), and her daughter Baiba Šuvcāne (1947-) followed with similar themes and interview materials from Livs living abroad, in more recent books $(2010,2012,2015)$. Books on Liv history and archeology have also started to appear in Latvia. As tourism develops, visitors to the picturesque Courland coast, the Turaida castle built on the site of the fortress of the ancient Liv chieftain Kaupo (famous for his early

13 This was followed by a similar book on Vepsian proverbs (Mälk, 1992), which included Livonian, Estonian, Votic, Karelian, and Russian equivalents.

14 The author can attest to this from personal experience, as Livonian lore seemed more interesting after learning that the residents of his mother's home district of Häädemeeste had included Livs. 
conversion to Christianity), and museums in areas formerly inhabited by Livs are also likely to be interested in such works.

Liv folk ark motifs, figures and themes from folklore, and text excerpts on souvenirs are also items that could be prepared for marketing. Researchers can help with such endeavors. Valts Ernštreits $(2012,2015)$ is already seeking ways to combine his knowledge of Liv heritage with the souvenir business and design enterprise he operates with his wife.

\section{Linguistic Life Support}

The recent improvement in opportunity to study Livonian at the university level in Latvia is encouraging, but without earlier immersion in Livonian-speaking settings, fluency and commitment to retain the language seem unlikely to develop. Short courses in introductory Livonian have been offered fairly regularly, for youths and adults, in various settings since 1989, including Sunday schools in Riga and weeklong summer camps at Irē (Mazirbe). Yet both Blumberga (2011a) and Ernštreits (2012) lament the lack of continuity, lack of a systematic teaching plan and materials, lack of training of the instructors, and lack of advanced courses.

Precise information about how many speakers are at various levels of proficiency is not available, but Ernštreits (2012) estimates that the number of beginning-level users of the Livonian language rose in the previous decade "for" [from? by?] about 50 to 150, but it is not clear how many of them identify as Liv or actually have Liv origin. In any case, despite the shortcomings of the instruction available, there has been a substantial increase in interest and ability in Livonian recently. Not all of this is attributable to participation in courses, as some study on their own or with the help of their grandparents, for example. Ernštreits counts about 15 people as "Livonian descendants who have fully mastered the language" and can communicate at least at the intermediate level. Another ten people are near the beginner-intermediate borderline, and use Livonian to communicate via a Web site, Skype, and other methods. The latter group tends to be younger and somewhat isolated from other users of the language. Ernštreits counts about 40 people in the world who can communicate at least at an intermediate level in Livonian nowadays, but only about half of them are of Liv origin. The growing ranks of Livonian speakers include linguistic researchers and students of non-Liv heritage.

The depressing reports about the impending extinction of the Livonian language are based on the ever-dwindling number of native speakers, who learned Livonian as their first language. No one born after the 1930s learned Livonian as the mother tongue (Blumberga, 2011a: 147). Kristin (2011) recalls that Livs in their 
villages felt they needed to speak Latvian to their children, to prepare them for school and modernity, of which their Latvian neighbors seemed have a better grasp. There was also pressure under the interwar Ulmanis regime to demonstrate loyalty to the Latvian state, and resistance to linguistic assimilation could be deemed unpatriotic. The last family situation where Livonian was spoken between native speakers came to an end when the esteemed traditional healer and language instructor Viktor Berthold (1921-2009) of Vaid/Kūolka lost his wife and brother in 1990 (Prozes \& Heinapuu, 2009). His cousin was Grizelda (n. Berthold) Kristin (1910-2013) of Campbellville, Ontario (near Toronto), who made an invaluable contribution to the collection of Livonian language learning materials. Five years before this reportedly last native speaker ${ }^{15}$ died at the age of 103 , her readings of the Livonian conversational passages in Boiko's textbook were recorded and made available on a compact disc (CD).

The disappearance of first-language Livonian speakers does not necessarily mean the end of fluency, since some younger speakers have managed to attain it. However, the opportunities for conversation are limited by the scattering of the few Livonian speakers between the Courland enclave, nearby regional centers like Ventspils, and Riga. The biggest concentration seems to be in the capital, where there has also been an attempt to arrange regular (monthly) meetings throughout the year, in a Liv cultural atmosphere, including conversation. Families gather for talks about traditions, singing (with explanations of the Livonian lyrics), dancing, eating of traditional foods, and some kind of practical activity (Stalte, 2016).

Such isolation has been transcended to some extent by the use of the computer network to communicate, but older speakers are unlikely to be online. Without the involvement of the latter, especially in oral communication, some nuances of pronunciation are vulnerable to being lost. For example, Ilse Lehiste's analysis of recordings of Livonian speakers, albeit with a very small sample, revealed that spoken Livonian has a three-quantity pattern when it comes to ratios of vowel sounds in the first and second syllable, which is analogous to the pattern in Estonian; the oldest speakers showed a kind of laryngealization, glottalization, or broken tone in certain stressed long syllables, while middle-aged and younger speakers were less likely to do so (2012: 79-81). While there are quite a few recordings of older

\footnotetext{
15 The loss of the last native speaker, proclaimed after several recent deaths, may still not have happened quite yet. Ernštreits said in his 2015 interview that Grizelda Kristin was the last good native speaker. Julgi Stalte noted in a recent personal communication (2016) that the oldest surviving speaker is a Riga resident who is 103 years old. She also expressed concern that an elderly speaker encountering an emphasis on grammatical correctness might feel intimidated or inadequate, and thereby hesitate to share whatever is remembered of the language.
} 
speakers available, including online, ${ }^{16}$ those who are not immersed in conversation with native (mother-tongue) speakers but used to a different (Latvian) context are likely to miss such a nuance and may have difficulty reproducing it even after a tutorial in such pronunciation.

Those most likely to take the trouble to learn Livonian or upgrade their knowledge of it are those who identify with this ethnic group. Self-identification is not always reflected in official registration, but there is fairly large number who are thus recorded in Latvia. In the post-Soviet era, the figure peaked at 204 in 1994, and was 172 in 2007 (Blumberga, 2011a: 147).

For the benefit of those without much previous contact with Livonian vocabulary, Linda Zonne has a Livonian language page on Facebook.. Other Facebook pages about the Livonian language and events allow for written exchanges. These occur mostly in Livonian, Latvian, and English. There is also an experimental interactive tutorial in Livonian vocabulary and grammar, which was developed with Renāte Blumberga's help. ${ }^{17}$

\section{Remnants of Folklore}

Considering how long Livs have been intermingling with their Latvian neighbors, there is little that is distinctive about their material objects, lifeways, celebrations, or many other aspects of their culture. Centenarian Grizelda Kristin, (2011) reports that already when she was growing up at the onset of the interwar period, Midsummer and all other holidays were celebrated exactly the same way by Livs as by their Latvian neighbors and jointly with them. Latvian songs were considered more prestigious and Latvian singers were invited to perform at weddings even before most of the Livs in the audience could understand the lyrics

16 The films of Nõmberg (1966), Säde (1991), Jegorov (1994), and Niglas (2005) are among the ones made by Estonians and available online. The early film of Linnus (1940) has only narration in Estonian. An interview with Grizelda Kristin (2015), who did the audio recording for Boiko's book, is also available online, with Latvian questions, Livonian answers, and an English transcript. Her readings of passages of Boiko's book are available at http://www.murre.ut.ee/arhiiv/otsi.php?mida=liivi\&otsi_andmebaasist=Otsi . The same site has many other recordings of Livonian speakers, including readings by Pētõr Damberg.

17 Zonne's Facebook tutorial is at https://www.facebook.com/media/set/?set=a. 368093056710069.1073741830.342195475966494\&type=3 . The tutorial that Blumberga helped to develop is available at http://testing.oahpa.no/livokel . It is sponsored by the OAHPA [Intelligent Computer-Assisted Language Learning] project of Norway's University of Troms $\emptyset$, which was originally designed to promote learning of Saami languages. 
(Loorits, 1936: xiv). In addition to Latvian wedding songs and Latvianized German love songs, the Livs also had been heavily influenced by the Latvian repertoire of herding, Shrovetide, and Midsummer songs (Salve, 2007: 231, 235).

Livs' exposure to foreign influences was earlier and more extensive than for neighboring peoples. Livs' involvement in the Viking-era trade network brought Byzantine, Greek, and Russian influences (evident in religious concepts and folk tales, for example) to their Daugava River settlements. Seafaring in the Baltic led to diffusion from Western Europe, particularly in the repertoire of instrumental folk music and folk dances (Salve, 2007: 235-236). Tampere notes that the ancient Livs had mingled with the Curonians to such an extent that the ethnic origin of their artifacts cannot be determined, and the Livs' fishing villages on the Courland coast had Latvian majorities already by the 16th century (1977: 141, citing the studies of E. Tõnisson [1970] and P. Johansen [1939], respectively). After the mid-19th century, Estonian seasonal workers were brought from Saaremaa Island to the Courland enclave to help in harvesting crops and fish (Linnus, 1982: 69).

As late as the 1980s, Salve (2007: 227) was able to enlist Pētõr Damberg as a guide to collect detailed accounts from Liv informants in the Courland enclave-about traditional calendric customs and beliefs, folk tales, and chants for healing. Yet the repertoire of old songs had disappeared for the most part, along with the older generation of informants (born in the 1860s) that Loorits had relied on. Only a decade after Loorits finished his fieldwork in 1937, Julius Mägiste did a study among the recently exiled Livs in Sweden, and found little of the rich variety of songs that Loorits had reported, according to Salve.

Nevertheless, some recollection of distinctive traditional songs remains--e.g., when songs about the awakening of the birds are sung. Livs used to believe that migrating birds were actually hibernating in secret places in winter, possibly in contact with the realm of the dead, and certain songs were sung during a springtime ritual (later associated with Easter) by young folks putting spruce boughs atop beach dunes, to attract the birds and bring good fortune for fishing, herding, crops, etc. (Tampere, 1970; Loorits (1998 [1926]: I: 27-28). Loorits thinks that this was the most important ritual in the Livonian annual calendar, and cites reports that some aspects of it were also found among Latvians of the Courland shore and Estonians of Muhu Island. ${ }^{18}$

This example suggests that the flow of cross-cultural influence was not just in one direction. With regard to songs, the direction of diffusion can be clarified by looking for mismatches between normally stressed syllables and long notes

18 The most elaborate form of this ritual was among the Livs, and echoes of it are recorded in nearby coastal areas easily accessible for contacts with the seafaring Livs. This suggest diffusion from Livs to neighboring peoples. 
(Tampere, 1970: 195). While rhythmically unclear and awkward phrasings point to borrowings of songs from another language, the use of distinctive word combinations familiar in cognate languages is evidence against such diffusion. Salve reports both types of evidence in the Livonian and Latvian repertoires, indicating mutual influence (2007: 234). Tampere (1970: 218-221) concludes that Livs adopted most of their wedding songs, love songs, and calendric songs from Latvians, while the latter group--especially in areas near the Livs' Courland enclave--sang some songs that were very similar in structure to the Livs' "awakening of the birds" genre, including some lullabies, Shrovetide songs, and Midsummer songs with the ligo refrain. ${ }^{19}$ In Livonian, ligo means 'to swing, sway, or rock'; it is related to the Estonian word liigu 'move!'

\section{Conclusion}

The tiny community of Livs has so far managed to avoid complete assimilation, despite tremendous challenges. Their old ways of life in the villages of the Courland enclave may continue to be preserved to some degree, perhaps supported by the development of tourism. Much of the traditional lore was left behind as Livonians relocated and adapted to urban life and new occupations, but is somewhat recoverable, through the accumulated documentation and archival recordings. Much

19 Two other examples can be offered from folk music. It seems likely that the Latvian lullaby phrase "Aija žǔžu" is derived from the Liv tradition of soothing babies with "Aiai žǔžu". Other Liv variants are "Eio, eio" and "Eija, eija", which resemble the Estonian "Eia, tuia", "Äiu-äiu, kussu-kussu", etc. and Setu Estonian "Ää-äh, ts'uu-ts'uu" or "Ää-äh, ljuu-ljuu." Mothers of any nationality would not be quick to adopt a style of lullaby singing from a foreign language. Instead, it seems more plausible that they would keep singing something they heard in their own or their former language. So the phrase probably appeared among Latvians via Latvianized Livs and/or Latvianized Estonians in the border region. The latter seems less likely, since the Livonian and Latvian phrases are virtually identical.

Lullabies and children's songs are among the most likely parts of a nationality's folk music heritage to be conserved generation after generation. Salve (2007: 233) suggests that they are among the "ethnically stable" songs with a clear function in a particular context. There is a striking similarity between a lullaby melody of the Livs (recorded by the Stalti Family in Riga, 1998, from the repertoire of Pētõr Damberg; another variant is in Loorits, 1936: 10) and a lullaby of the Ingrian Finns (recorded by the Karelian Folk Music Ensemble, Burlington VT: Gadfly, 1997). Perhaps the tune is part of their common heritage, dating back to the time of their linguistic separation, some 2,000 years ago.

The second example is the song "Pūt, vējiniı!", which served as a substitute anthem for Latvians during the Soviet regime. It derives from an older and more complex Liv folk song, "Pūgõ tūḷ!" [Blow, Wind!], which seems to date from the time the Vidzeme Livs sailed to visit Courland. 
of the written record is in languages not spoken by most Livonians, but several of the leading figures among them have studied in Estonia or Finland and can serve as translators for the majority of their group who have not.

There are many persons who identify as Liv even if they are unable to communicate in their ancestors' language. This shows that their ethnic identity is not necessarily tied to the language. Just as the Irish, Jews, American Indian tribes, and other groups have held onto their ethnic identity and cultural distinctiveness even after adopting another language, Livs show an interest in maintaining certain traditions and avoiding complete assimilation. Certain Livonian words (e.g., jem $\bar{a}$ 'mother'), expressions (jõvvõ $\bar{\imath} e d \tilde{o}$ 'good night'), and superstitious practices (e.g., pouring some vodka or tossing some bread into the water near shore at a boatlaunching, to ensure the protection of the Sea Mother) are commonly maintained, even if Latvian is the primary language (Mägi's 2001 interview with Julgi Stalte).

The loyalty of the Liv minority is no longer a matter of concern to Latvians, if there ever was a valid reason for such worry. Livs' numbers have dwindled to virtual insignificance, the border with Estonia has long been stable, all the nationalities of the Baltic countries suffered under the Soviet occupation, and they all worked together to restore national independence. As Latvia has become part of international alliances like the European Union and the North Atlantic Treaty Organization, it is less suspicious of other countries that have shown such a keen interest in studying and assisting the Livs and are more amenable to joint projects that benefit its Finnic-speaking aboriginal minority.

The Latvian government has taken several important supportive steps. Even before the full restoration of independence in August, a January 1991 law on ethnic minorities' development and right to cultural autonomy recognized Livs as an aboriginal minority whose ethnic identity and historical environment deserved preservation. In October 1991 came the finalization of the creation of a Livonian Shore district, which involved historic preservation of the buildings, furnishings, and landscape; documentation; infrastructure development; support of research, education, and cultural events. A 1999 law provided a special benefit for Livs by removing the cost of changing their officially registered ethnic designation from "Latvian" to "Liv", if they opted to take advantage of this. The 2000 language law recognized Livonian as an aboriginal minority language, entitled to preservation, protection, and development. State funding has supported language classes, children's camps, archeological excavations, documentation work, publications, conferences, non-profit organizations, etc. However, the shuffling of responsibilities between various ministries and agencies, as well as the 2008 recession's reduction of revenues, led to interruptions of progress (Blumberga, 2011a: 146-147, 149-151).

Livs have taken advantage of new resources and opportunities that benefit them as a group. They have adapted well to the computer age, and are using the 
Internet, Facebook, and other means of networking to share their knowledge of their heritage and reinforce a sense of community. Considering their small number, they have clearly established themselves as overachievers in the realms of politics, folk music performance and research, linguistic and cultural preservation. Since several of their leaders have established careers involving Liv matters, it seems safe to say that Liv participation in scholarship and activism will continue for several more decades. Several new Liv folk music ensembles and choirs have formed in the new century (Blumberga, 2011b: 365-366). Organizations and periodicals that had to cease their operations in the Soviet era have been resurrected. Although the Latvian language dominates in them now, this also facilitates outreach to Latvianized Livs.

The crucial factor for the long-term viability of the Livs as a distinctive ethnic group is socialization of youngsters. This involves fostering ethnic pride, passing on knowledge of traditions, and encouraging interest in exploring the heritage. In these respects, the current trends bode rather well for the persistence and even some resurgence of the Liv nationality.

\section{References}

Blumberga, Renāte. (2004) Oskar Loorits ja liivlased. Mäetagused 24, pp. 9-19. Tartu: Eesti Kirjandusmuuseum. Retrieved from http://www.folklore.ee/tagused/nr24/blumberga.pdf .

Blumberga, Renāte. (2011a). Liivlased 19.-21. sajandil. In Blumberga et al. (2011, pp. 127-154).

Blumberga, Renāte. (2011b). Liivlaste muusikaelu. In Blumberga et al. (2011,pp. 349-366).

Blumberga, Renāte. (2011c). Liivlaste ärkamisaeg ja hõimuliikumine. In Blumberga et al. (2011,pp. 155-190).

Blumberga, Renāte, Tapio Mäkeläinen, and Karl Pajusalu (eds.). (2011) Liivlased:

Ajalugu, keel ja kultuur. Tallinn: Eesti Keele Sihtasutus. [Latvian edition 2013] Boiko, Kersti. (2000) Lìvõ kēll: Piški optobrōntoz. Riga: Līvõd Īt.

Cimermanis, Saulvedis. (2003) The Livs of Svētciems Pagasts in the Late 18th and 19th Century. Pro Ethologia 15, pp. 11-27.

Ernštreits, Valts. (1998) Ma akūb sīnda vizzõ, tūrska! Riga: Līvõ Kultūr Sidām.

Ernštreits, Valts. (2011) Kui sūolõbõd līvlizt. Riga: Līvõ Kultūr Sidām.

Ernštreits, Valts. (2012) Livonian in the 21st century. Études finno-ougriennes 44.

Paris: Association pour le développement des études finno-ougriennes. Retrieved from http://efo.revues.org/675 . 
Ernštreits, Valts. (2013) Liivi kirjakeel. Tartu: Tartu Ülikooli Kirjastus. [Latvian edition 2011]

Ernštreits, Valts. (2015) Interviewed in Estonian on June 30 by Jaak Urmet, Parts I \& II. Kultuurimeeter: Inimese mõõde. Tallinna TV. Retrieved from https://www.youtube.com/playlist?list=PLsdJp_7Yevy0KI1Dvs_FJ6UYfEuC ZEX-3 .

Hint, Mati. (2009) Pētõr Dambergi kirjavahetus hõimuliikumise kõrgajal (tema 100. sünniaastapäeva puhul). Keel ja kirjandus 3, pp. 226-228.

Jegorov, Georg (dir.). (1994) Hõimupuи: Liivlased. Eesti Televisioon, June 30. Retrieved from http://arhiiv.err.ee/vaata/764 .

Karro, Bruno. (1998) Metsapoole ja Häädemeestega seoses. Häädemeeste elu, 18:2, pp. 35-37.

Kristin, Grizelda. (2011) Interviewed by Zoe Dirse. Toronto: Endangered Language Alliance. Retrieved from http://elalliance.com/livonian/ .

Linnus, Ferdinand (dir.). (1940) Liivi rannikult. Eesti Kultuurifilm. Excerpts are in Jegorov (1994).

Linnus, Tanel. (1982) Kuramaa liivlaste sotsiaalne struktuur 20. sjaandi algul. In Jüri Linnus (ed.), Läänemeresoomlaste etnokultuuri küsimusi (pp. 67-70), Tallinn: Valgus.

Loorits, Oskar. (1936) Volkslieder der Liven. Tartu: Õpetatud Eesti Selts.

Loorits, Oskar. (1998 [1926-1928] \& 2000) Liivi rahva usund I-III \& IV-V. Tartu: Eesti Kirjandusmuuseum.

Mägi, Marko. (2001) Julgi Stalte--eelviimane mohikaanlane? Eesti Ekspress, July 26. Retrieved from http://epl.delfi.ee/news/melu/ee-persoon-julgi-stalteeelviimane-mohikaanlane?id=50890182 .

Mäkeläinen, Tapio. (2010) Maailma viimane emakeelne liivlane sai 100-aastaseks. Fenno-Ugria, March 19. Retrieved from http://m.finugor.com/en/node/13126. Mälk, Vaina. (1981) Liivi vanasõnad: Eesti, vadja ja läti vastetega I-II. Tallinn: Eesti Raamat.

Mälk, Vaina. (1992) Vepsa vanasõnad: Eesti, vadja, liivi, karjala ja vene vastetega I-II. Tallinn: Eesti Teaduste Akadeemia Keele ja Kirjanduse Instituut.

Moseley, Christopher. (2014) Livonian--the most endangered language in Europe?

Eesti ja soome-ugri keeleteaduse ajakiri / Journal of Estonian and Finno-

Ugric Linguistics 5:1, pp. 61-75. Retrieved from http://jeful.ut.ee/index.php/JEFUL/article/view/jeful.2014.5.1.04/42 .

Nevis, Joel Ashmore. (1989) On Case in Livonian. In Joel Ashmore Nevis (ed.), FUSAC '88 ACEFO: Proceedings of the Sixth Annual Meeting of the FinnoUgric Studies Association of Canada (pp. 95-109), Lanham, MD: University Press of America. 
Niglas, Liivo (dir.). (2005) Julgi vägi. Estonian Television program, Nov. 22. Retrieved from https://arhiiv.err.ee/vaata/eesti-lood-julgi-vagi .

Nõmberg, Endel (dir.). (1966) Liivi rannal. Eesti Telefilm. Retrieved from https://arhiiv.err.ee/vaata/liivi-rannal .

Pajusalu, Karl. (2010) Jäljed Liivimaa liivi keelest. Sirp, Sept. 27. Retrieved from http://www.sirp.ee/s1-artiklid/varamu/jaeljed-liivimaa-liivi-keelest/ .

Pajusalu, Karl, Arvo Krikmann, and Eberhard Winkler. (2009) Lexical Relations between Salaca Livonian and Estonian Dialects. Linguistica Uralica 45: 4, pp. 283-298. Retrieved from http://www.kirj.ee/public/

Linguistica_Uralica/2009/issue_4/ling-2009-4-283-298.pdf .

Säde, Enn (dir.). (1991) Liivlaste lood. Eesti Telefilm. Retrieved from https://arhiiv.err.ee/vaata/liivlaste-lood .

Salve, Kristi. (1995) Liivi muinasjutte. Tallinn: Perioodika.

Salve, Kristi. (2007) Liivi rahvausundist ja folkloorist. Paar sammukest 23, pp. 213272. Tartu: Eesti Kirjandusmuuseum.

Sāmīte, Dace. (2015) Liivi ranna loodust ilmestavad luited ja metsalaamad. Eesti loodus, June/July, pp. 12-17.

Šmidchens, Guntis. (2014) The Power of Song: Nonviolent National Culture in the Baltic Singing Revolution. Seattle: University of Washington Press.

Specter, Michael. (1997) Riga Journal; Baltic's Onetime Rulers Have Shrunk to a Handful. New York Times, Dec. 4, 1997. Retrieved from http://www.nytimes.com/1997/12/04/world/riga-journal-baltic-s-onetimerulers-have-shrunk-to-a-handful.html .

Sutrop, Urmas. (2011) Liivlaste Metsepole maakonna ulatusest põhja suunas muistse iseseisvuse ajal. In Blumberga et al. (pp. 105-116).

Šuvcāne, Baiba. (2010) Senais lībiešu ciems Kolka. Riga: Jumava.

Šuvcāne, Baiba. (2012) Lībiešu krasti stāsti. Riga: Jumava.

Šuvcāne, Baiba. (2015) Sauc par Vaidi mūsu ciemu. Riga: Lauku avīze.

Šuvcāne, Valda Marija. (2002) Lībiešu ciems, kura vairs nav. Riga: Jumava.

Šuvcāne, Valda Marija (ed. \& trans.). (2003) Lībiešu folklora. Riga: Jumava.

Tampere, Herbert. (1970) "Lindude äratamine" liivlaste rahvatraditsioonis. In J. Linnus (ed.), Läänemeresoomlaste rahvakultuurist (pp. 193-225), Tallinn: Valgus.

Tampere, Herbert. (1977). Mõned mõtted liivi rahvalaulust. In Ingrid Rüütel (ed.), Soome-ugri rahvaste muusikapärandist (pp. 135-148), Tallinn: Eesti Raamat.

Vääri, Eduard. (1970) Liivlased ja liivi keel. In A. Valmet, P. Palmeos, and J. Peegel (eds.), Saaremaast sajaanideni (pp. 74-88), Tallinn: Valgus.

Vääri, Eduard. (1998) Liverna och deras språk. Finsk-ugriska seminariets rapporter 2, Gothenburg, Sweden: Gothenburg University. Revised version of his 1970 article, translated into Swedish by Juhan Tuldava. 
Viitso, Tiit-Rein and Valts Ernštreits. (2012) Līvõkīel-Ēstikīel-leţkīel sõnārōntõz. Tartu \& Riga: Tartu Ülikool \& Latviešu valodas agentura. Retrieved from http://www.murre.ut.ee/liivi/ .

Zemītis, Guntis. (2011) Liivlased: Vanim ajalugu (10.-16. sajand). In Renāte Blumberga et al. (pp. 75-104). Tallinn: Eesti Keele Sihtasutus. 